\title{
CT-based analysis of malignant tumor volume and localization. A preliminary study
}

\section{Análise e localização do volume de tumor maligno por meio da TC. Estudo preliminar}

\author{
Marcelo Gusmão Paraiso Cavalcanti* \\ Denise Takehana dos Santos** \\ Andreia Perrella*** \\ Michael Walter Vannier $* * * *$
}

\begin{abstract}
The purpose of this study was to correlate 3D-CT (3D computed tomography) volume measurements of malignant tumors with the response to treatment, and to observe bone invasion in these lesions applying a specific imaging protocol. We analyzed 17 individuals with maxillofacial malignant lesions who were submitted to spiral CT (2D-CT). The original data were transferred to an independent workstation using a 3D volume rendering package software, which was used by two examiners to obtain area and volume measurements of the lesions, independently, three times each, prior to and after treatment. The segmentation protocol was applied for the assessment of bone involvement. The difference between imaging and gold standard values was not considered significant $(\mathrm{p}>0.05)$. Regarding bone invasion, three false-negatives were obtained using MPR-CT (multiplanar reconstruction) and no false-negatives were obtained using the 3D segmentation protocol. The use of 3D-CT may be a differential and important factor for expanding options regarding the localization, dimension, and clarification of lesion components.
\end{abstract}

DESCRIPTORS: Tomography; Wounds and injuries; Image processing, computer-assisted; Face; Neoplasms.

RESUMO: O propósito desta pesquisa foi correlacionar medidas volumétricas de lesões malignas em reconstruções tridimensionais (TC-3D) com a resposta ao tratamento e verificar o grau de envolvimento ósseo dessas lesões, aplicando-se protocolos de imagem específicos associados à computação gráfica. Foram estudados 17 indivíduos portadores de lesões malignas maxilofaciais que haviam sido submetidos à tomografia computadorizada espiral (TC-2D). Os dados originais foram transferidos para uma estação de trabalho independente, utilizando um programa para imagens volumétricas, com o qual dois observadores obtiveram medidas de área e volume das lesões, independentemente, 3 vezes cada um, no pré e pós-tratamento. O protocolo de segmentação foi aplicado para avaliação do comprometimento ósseo. A diferença entre os valores obtidos na análise da TC e no padrão ouro não foi considerada significante $(p>0,05)$. Considerando o envolvimento ósseo, obtiveram-se três falsos-negativos em análise das reconstruções multiplanares (TC-RMP) e nenhum falso-negativo em análise da TC-3D por meio do protocolo de segmentação. A utilização de recursos como reconstrução em TC-3D pode ser um fator diferencial e de grande valia para aumentar opções quanto a localização, dimensões e esclarecimento de componentes de diversas lesões.

DESCRITORES: Tomografia; Ferimentos e lesões; Processamento de imagem assistida por computador; Face; Neoplasias.

\section{INTRODUCTION}

Recent reports have shown that tumor volume is a reliable piece of information for treatment planning ${ }^{19}$, and that it can also predict the outcome of radiotherapy for head and neck cancer $^{4,9,12,16,20,22}$. Multiplanar reconstructed (MPR) images from computed tomography (CT) play an important role in both pre- and postoperative eval- uation of oral and maxillofacial abnormalities s, $^{9,13,15}$. The standard method for assessing the response of tumor to treatment is to determine its changes in maximum cross-sectional area ${ }^{23}$. Two-dimensional (2D) measurements may misrepresent changes in tumor size because they disregard alterations in the third dimension ${ }^{15}$.

* Professor; **PhD student; ***Dental Practice - Department of Oral and Maxillofacial Radiology, School of Dentistry, University of São Paulo.

**** Professor, Department of Radiology, School of Medicine, University of Iowa. 
Cavalcanti MGP, Santos DT, Perrella A, Vannier MW. CT-based analysis of malignant tumor volume and localization. A preliminary study. Braz Oral Res 2004;18(4):338-44.

The use of specific programs associated to CT allows the reconstruction of three-dimensional images of the craniofacial structures ${ }^{7,8,23,24}$. Thus, the visualization of soft tissues becomes possible as well as their relationship with adjacent bone structures due to the high image quality. According to the related literature, validating the imaging methodology using MPR-CT and 3D-CT is important for the establishment of adequate protocols, which will make the classification of the pathological process, the development of an effective therapeutic conduct, and the evaluation of patients ${ }^{1}$ easier. 3D-CT is considered a useful tool to complement 2D-CT in the evaluation of several pathologies that affect the maxillofacial complex ${ }^{7,21,23,24}$. Computerassisted radiology is used for diagnostic biopsy, preoperative planning, intra-operative guidance and postoperative assessment. More accurate determination of changes in tumor size may be obtained using 3D volume measurements, with consequent implications for assessment of response to therapy ${ }^{23}$.

Our purpose was to correlate the 3D-CT volume measurements of malignant lesions with their response to treatment, and to observe bone invasion of those lesions using a specific imaging protocol.

\section{MATERIAL AND METHODS}

We analyzed 17 patients with malignant lesions (lymphoma, carcinoma, and sarcoma). The patients were referred to spiral CT imaging (Toshiba X-Press, Toshiba Medical, Tustin, CA, USA) at $120 \mathrm{kVp}$ and $200 \mathrm{~mA}$, using a $512 \times 512$ matrix and $3 \mathrm{~mm} / 1 \mathrm{sec}$ of table feed to produce $3 \mathrm{~mm}$ thick slices with $1.5 \mathrm{~mm}$ reconstruction interval prior to and after treatment. A scanning filter $(\mathrm{FC})$ of 20 and field of view (FOV) of $20.3 \mathrm{~cm}$ were used, as well as intravenous contrast $(150 \mathrm{ml}$ of Conray 60, Mallinckrodt Medical Inc., Saint Louis, MO, USA), which permitted the visualization of soft tissue involvement and aided in the delineation of the lesion. The data sets of this investigation were transferred to a computer workstation (DELL Precision 420 NT 4.0 hardware, Estrela do Sul, RS, Brazil) with Vitrea ${ }^{\circledR} 2.3$ software (Vital Images Inc., Plymouth, MN, USA) to generate interactive $3 \mathrm{D}$ volume rendered images and MPR images.

The tumor was observed due to the increased vascularity and contrast enhancement peripheral to the lesion. It was possible to localize the contour of the tumor, visualizing all of its borders in relation to the anatomical bone structure (Figures 1A, $\mathrm{B}, \mathrm{C})$. Measurements of area and volume were obtained using the crosshair tool (Figures 1A, B, C) and selecting the largest diameter of the images of the lesions in axial, coronal and sagittal (MPR) reconstructed views, according to previous validated methodology ${ }^{9}$. Volumetric measurements were made by manual contour delineation of these three views using the Vitrea ${ }^{\circledR}$ software tools, which automatically defined the range of CT densities in the region of interest. Two observers, on three different occasions separated by several weeks, traced the contour of the lesions using a computer mouse and making their own decision as to the boundaries. They were all submitted to previous training. The software tools automatically displayed the lesions in $3 \mathrm{D}$ reconstructed images with the corresponding measurements of area and volume (Figure 2A). Applying the same methodology, it was possible to compare the images obtained prior to and after treatment in order to analyze the response to treatment (Figures 2C and 3A-F).
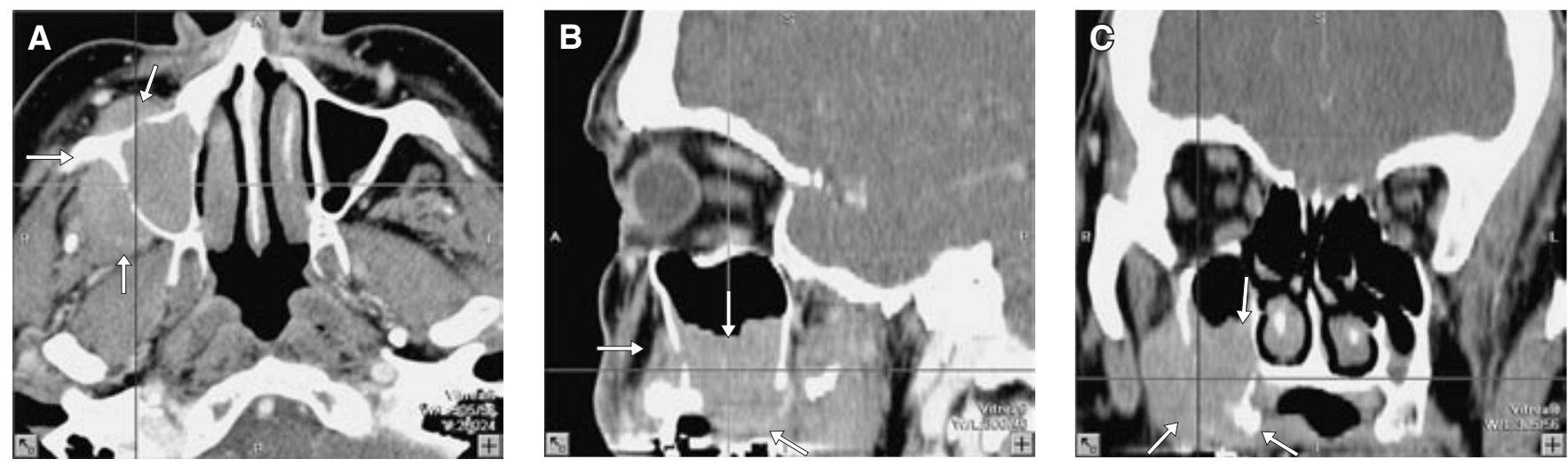

FIGURE 1 - CT images of lymphoma at the right maxillary sinus in axial (A), sagittal (B), and coronal (C) view reconstructed images, showing bone destruction on the inferior maxillary sinus wall (arrows). 
Cavalcanti MGP, Santos DT, Perrella A, Vannier MW. CT-based analysis of malignant tumor volume and localization. A preliminary study. Braz Oral Res 2004;18(4):338-44.
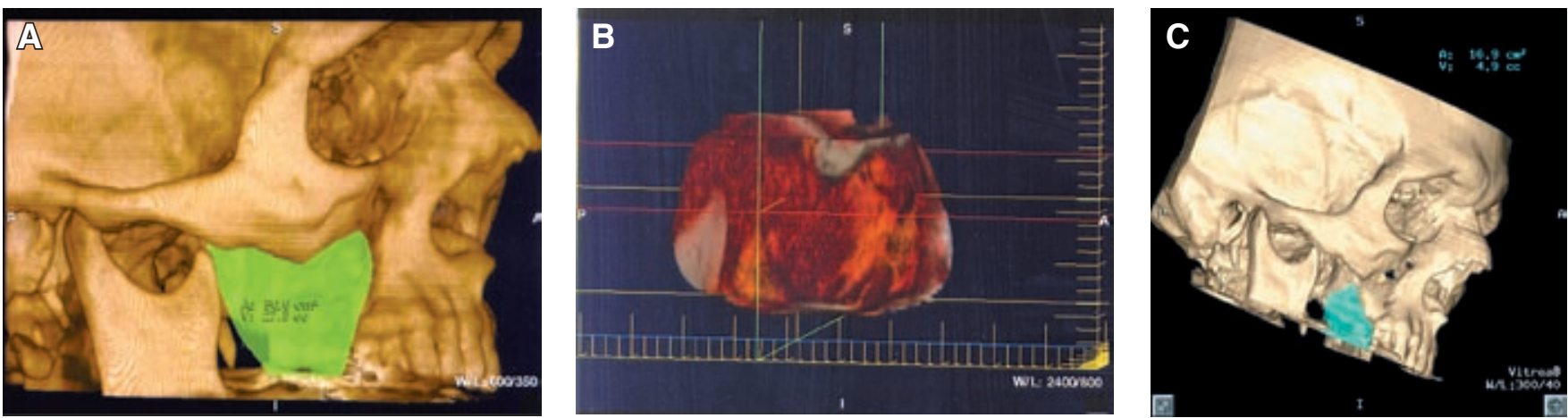

FIGURE 2 - A: Lateral view of the 3D-CT reconstruction of the soft tissue mass (green), with area $=50.6 \mathrm{~cm}^{2}$ and volume $=27.5 \mathrm{cc}$. B: $3 \mathrm{D}-\mathrm{CT}$ segmentation protocol depicting the lymphoma in red with white streaks, demonstrating bone involvement. C: 3D-CT reconstruction imaging showing the follow-up of treatment with reduction in the size of the lesion (light blue) (area of $16.9 \mathrm{~cm}^{2}$, and volume of $4.9 \mathrm{cc}$ ).
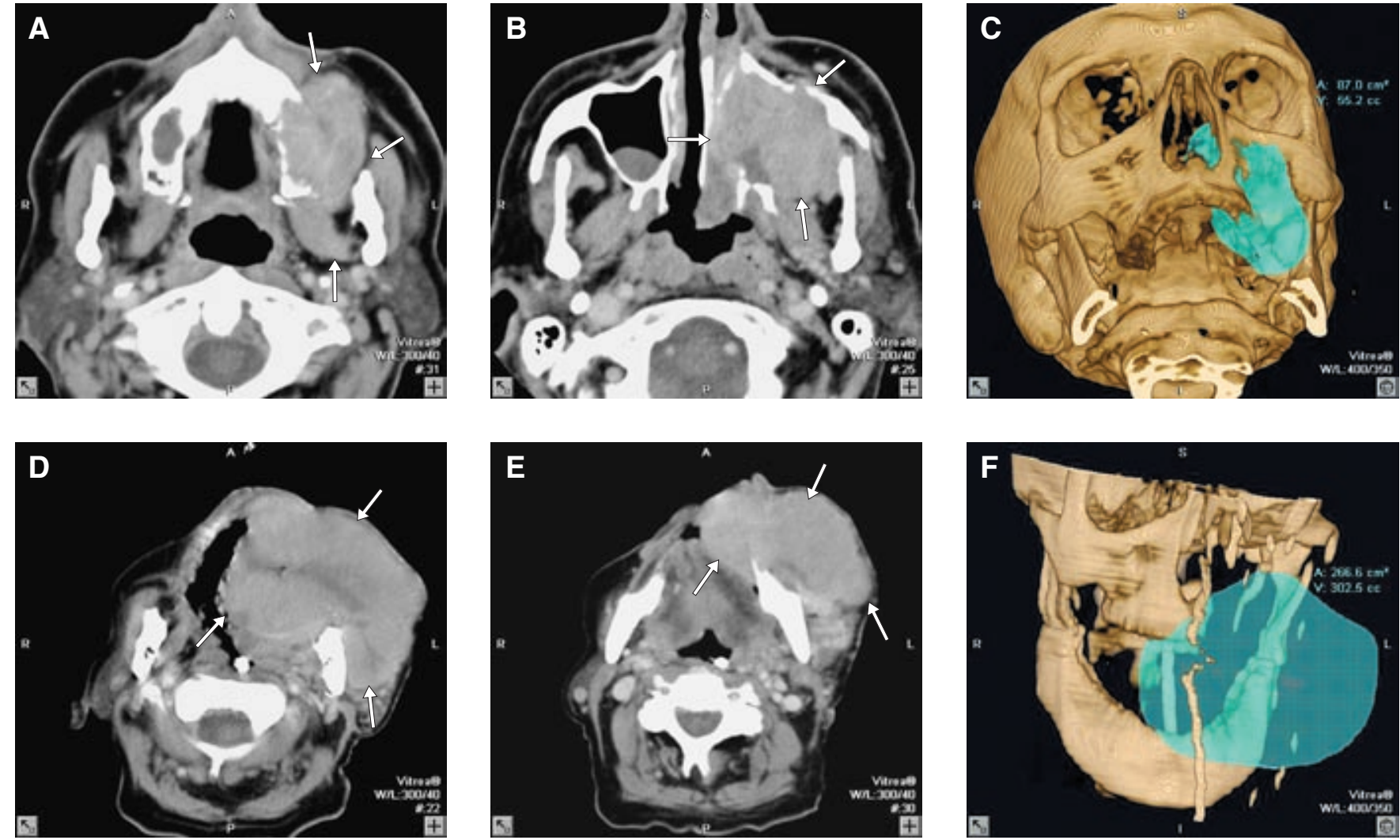

FIGURE 3 - A and B: Axial views at soft tissue window level showing fibrosarcoma on the left side involving the maxillary sinus, pterigoid process, lateral pterigoid muscles, nasal fossa, maxilla, and zygomatic bone (arrows); C: 3D-CT frontal view, showing the tumor mass in 3D (light blue), with area $=87.0 \mathrm{~cm}^{2}$ and volume $=55.2 \mathrm{cc}$, and its relationship with adjacent structures, such as the maxilla and zygomatic bone (causing destruction), and the nasal cavity; D and E: Axial CT images showing recurrence, depicting a large tumor mass involving the left side of the maxilla and extending to the parotid gland (arrows); F: 3D-CT image showing an increase in tumor mass in 3D (light blue), with area $=266.6 \mathrm{~cm}^{2}$ and volume $=302.5 \mathrm{cc}$, with large bone destruction of the left side of the face.

For the analysis of bone invasion, we repeated the same steps described above, localizing the largest diameter of the images of the lesions in axial, coronal and sagittal views and making the contour delineation of these three images. The specific tool for $3 \mathrm{D}$ volume rendering software package (seg- 
Cavalcanti MGP, Santos DT, Perrella A, Vannier MW. CT-based analysis of malignant tumor volume and localization. A preliminary study. Braz Oral Res 2004;18(4):338-44.
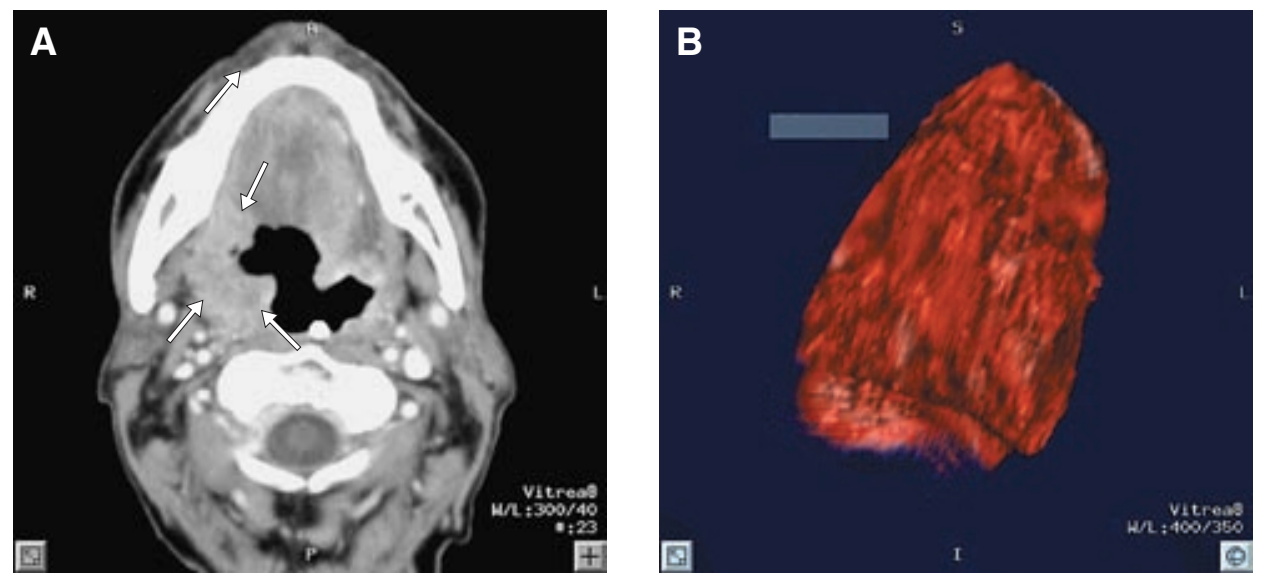

FIGURE 4 - A: Axial view at soft tissue window level showing squamous cell carcinoma on the right side of the floor of the mouth, involving the parapharyngeal space (arrows); B: 3D-CT segmentation protocol depicting the entire lesion in red, demonstrating no bone involvement.

mentation protocol) was then applied. The lesion appeared segmented from the anatomical adjacent bone structures, providing a clear perception of bone anatomy and of the destruction caused by the tumor mass. This is depicted as white streak marks that show bone involvement in contrast to the red color representing the soft tissue mass (Figure 2B). When no bone involvement was found, the lesion appeared totally red in color (Figures 4A and $\mathrm{B}$ ). These different color tables are specific tools of the computer graphic system, applied to the CT data and based on CT density. The 3D images were viewed using rotation, translation, and a fly-through modes, making the evaluation of bone involvement possible (Figure 3C). The clinical and/or surgical findings (medical records) were considered the gold standard corroborating the diagnoses of the maxillofacial lesions.

ANOVA (Analysis of Variance) and Chi-square tests with SPSS (Statistical Package for the Social Sciences, Chicago, IL, USA) software were used to gather the data file and carry out the statistical analysis, as well as to test the validity of the methodology ${ }^{24}$.

\section{RESULTS}

Table 1 presents the differences in area and volume prior to and after treatment. The difference between the gold standard and imaging values was not considered significant $(p>0.05)$. In all patients submitted to radiotherapy, the tumor volume and area decreased considerably and the values were in agreement with therapy. The opposite happened with the recurrence cases (volume and area increased considerably). In both situations, an agreement with the clinical and surgical findings was observed.
TABLE 1 - Differences in measurements (prior to and after treatment) of area and volume in patients with malignant neoplasms.

\begin{tabular}{l|r|r|c}
\hline \multicolumn{1}{c|}{ Tumor } & $\begin{array}{c}\text { Area } \\
\text { variation }\end{array}$ & $\begin{array}{c}\text { Volume } \\
\text { variation }\end{array}$ & $\begin{array}{c}\text { Clinical } \\
\text { and } \\
\text { treatment } \\
\text { stages }\end{array}$ \\
\hline Carcinoma & $42.73 \%$ & $89.99 \%$ & $\mathrm{R}$ \\
\hline Carcinoma & $8.66 \%$ & $13.26 \%$ & $\mathrm{R}$ \\
\hline Carcinoma & $45.47 \%$ & $192.01 \%$ & $\mathrm{R}$ \\
\hline Carcinoma & $29.35 \%$ & $33.99 \%$ & $\mathrm{R}$ \\
\hline Carcinoma & $-36.28 \%$ & $-37.98 \%$ & $\mathrm{~T}$ \\
\hline Lymphoma & $-4.03 \%$ & $-37.11 \%$ & $\mathrm{~T}$ \\
\hline Osteosarcoma & $28.80 \%$ & $43.55 \%$ & $\mathrm{R}$ \\
\hline Fibrosarcoma & $99.52 \%$ & $274.44 \%$ & $\mathrm{R}$ \\
\hline Lymphoma & $-74.23 \%$ & $-87.56 \%$ & $\mathrm{~T}$ \\
\hline Fibrosarcoma & $31.78 \%$ & $50.44 \%$ & $\mathrm{R}$ \\
\hline Carcinoma & $12.68 \%$ & $37.97 \%$ & $\mathrm{R}$ \\
\hline Carcinoma & $67.05 \%$ & $251.08 \%$ & $\mathrm{R}$ \\
\hline Carcinoma & $28.60 \%$ & $45.53 \%$ & $\mathrm{R}$ \\
\hline Lymphoma & $-29.76 \%$ & $-35.89 \%$ & $\mathrm{~T}$ \\
\hline Carcinoma & $23.40 \%$ & $28.21 \%$ & $\mathrm{R}$ \\
\hline Carcinoma & $-36.27 \%$ & $-42.14 \%$ & $\mathrm{~T}$ \\
\hline Osteosarcoma & $43.18 \%$ & $58.25 \%$ & $\mathrm{R}$ \\
\hline \hline Rym & &
\end{tabular}

$\mathrm{R}$ : recurrence, $\mathrm{T}$ : radiotherapy.

Inter- and intra-examiner reliability are shown in Table 2, with the interval ranging from $11.15 \%$ to $19.59 \%$, and the standard deviation from $9.86 \%$ to $17.89 \%$. The largest difference was found between inter-examiner volume measurements (19.59\%).

Table 3 shows three false-negatives in axial and in MPR-CT images (82.36\% of agreement). It was not possible to identify bone involvement 
Cavalcanti MGP, Santos DT, Perrella A, Vannier MW. CT-based analysis of malignant tumor volume and localization. A preliminary study. Braz Oral Res 2004;18(4):338-44.

TABLE 2 - Analysis of measurements of the two examiners.

\begin{tabular}{l|c|c|c|c|c|c}
\hline \hline Reproducibility analysis & $\begin{array}{c}\text { Intra A } \\
\text { exam 1 }\end{array}$ & $\begin{array}{c}\text { Intra A } \\
\text { exam 2 }\end{array}$ & $\begin{array}{c}\text { Inter A } \\
\text { exam }\end{array}$ & $\begin{array}{c}\text { Intra V } \\
\text { exam 1 }\end{array}$ & $\begin{array}{c}\text { Intra V } \\
\text { exam 2 }\end{array}$ & $\begin{array}{c}\text { Inter V } \\
\text { exam }\end{array}$ \\
\hline Mean & $11.15 \%$ & $14.16 \%$ & $17.56 \%$ & $13.15 \%$ & $17.43 \%$ & $19.59 \%$ \\
\hline Standard deviation & $9.86 \%$ & $11.50 \%$ & $16.44 \%$ & $10.57 \%$ & $17.89 \%$ & $17.37 \%$ \\
\hline \hline
\end{tabular}

$\mathrm{A}=$ area, $\mathrm{V}=$ volume, Intra A exam 1 = area measurements intra-examiner 1 , Intra A exam $2=$ area measurements intra-examiner 2 , Inter $\mathrm{A}$ exam $=$ area measurements inter-examiners 1 and 2 , Intra $\mathrm{V}$ exam $1=$ volume measurements intra-examiner 1 , Intra $\mathrm{V}$ exam 2 = volume measurements intra-examiner 2 , Inter $\mathrm{V}$ exam = volume measurements inter-examiners 1 and 2.

TABLE 3 - Analysis of bone destruction observed on axial + MPR, and on the 3D segmentation protocol images versus the gold standard.

\begin{tabular}{|c|c|c|c|}
\hline Tumor & $\begin{array}{l}\text { Axial + } \\
\text { MPR }\end{array}$ & $\begin{array}{c}\text { 3D } \\
\text { segmentation }\end{array}$ & $\begin{array}{c}\text { Gold } \\
\text { standard }\end{array}$ \\
\hline Carcinoma & 0 & + & + \\
\hline Carcinoma & + & + & + \\
\hline Carcinoma & 0 & 0 & 0 \\
\hline Carcinoma & + & + & + \\
\hline Carcinoma & 0 & 0 & 0 \\
\hline Lymphoma & + & + & + \\
\hline Osteosarcoma & + & + & + \\
\hline Fibrosarcoma & + & + & + \\
\hline Lymphoma & + & + & + \\
\hline Fibrosarcoma & + & + & + \\
\hline Carcinoma & 0 & + & + \\
\hline Carcinoma & 0 & 0 & 0 \\
\hline Carcinoma & + & + & + \\
\hline Lymphoma & + & + & + \\
\hline Carcinoma & 0 & + & + \\
\hline Carcinoma & 0 & 0 & 0 \\
\hline Osteosarcoma & + & + & + \\
\hline
\end{tabular}

0: without osseous involvement, +: with osseous involvement. MPR: multiplanar reconstructed images = coronal + sagittal

in three of the 17 cases. However, regarding the 3D segmentation protocol, complete agreement was found (confirmed by the histopathological and surgical findings).

\section{DISCUSSION}

The development of computer graphic programs has facilitated the interactive visualization and the qualitative and quantitative analyses necessary for craniofacial surgical planning ${ }^{1,3,7,8,14,15}$. These advances allowed more detailed bone struc- ture analysis, improving imaging interpretation in comparison with conventional radiographs ${ }^{6,11,25}$. In our experiment, it was possible to obtain the soft tissue mass, to segment, to manipulate, and to visualize the anatomical structures using $3 \mathrm{D}-\mathrm{CT}$ volume rendering using an independent workstation.

Hermans et al. ${ }^{16}$ (1998) analyzed measurements taken by five examiners, in four different sessions. Significant inter-examiner variation was reported, and the intra-examiner variation was also significant. According to the authors, this variation could have been smaller if the measurements had been taken by a single trained examiner, since the inter-examiner variation was $89.3 \%$ while the intra-examiner one corresponded to $6.4 \%$. In our study, better results were obtained for inter-examiner variation (19.59\%). This happened because we employed an MPR method to identify the lesion with the aid of intravenous contrast and with a fine reconstruction interval of $1.5 \mathrm{~mm}$, which made it possible to obtain reconstruction with better resolution. This facilitated the localization of the lesion and consequently the acquisition of volume in 3D. However, we consider that with the introduction of multislice CT, which allows the isotropic scanning of a whole volume in 16 slices in 0.5 seconds, the reproducibility will be strongly improved. Also, the determination of volume and area differences between imaging and clinical aspects can express more fidelity since the scan parameters regarding slice thickness and interval of reconstruction can be less than $2 \mathrm{~mm}$ and $1 \mathrm{~mm}$, respectively.

According to the related literature, the importance of correctly estimating the size of a tumor is evident because it will determine the treatment procedures according to the development of the neoplasm ${ }^{4,6,9,12,16,18-20,22,23}$. According to Doweck et al. ${ }^{12}$ (2002), only $14.1 \%$ of the patients with tumors larger than $19.6 \mathrm{cc}$ survive, while $41.5 \%$ survive when the tumors are smaller than $19.6 \mathrm{cc}^{12}$. In our study, a protocol was established to measure the volume of the tumors before and after treatment in the analysis of bone structures, improving imag- 
Cavalcanti MGP, Santos DT, Perrella A, Vannier MW. CT-based analysis of malignant tumor volume and localization. A preliminary study. Braz Oral Res 2004;18(4):338-44.

ing interpretation in comparison to conventional radiographs $s^{6,11,24}$. According to our experiment, it was possible to obtain the soft tissue mass of tumors, to segment, to manipulate, and to visualize the anatomical structures using 3D-CT volume rendering using an independent workstation.

Cavalcanti, Vannier ${ }^{9}$ (2000) validated a method to obtain volume measurements in maxillofacial neoplasms of the oral cavity. In the present study, the authors were able to measure the area and the volume of the lesions using 3D-TC. The latter experiment was of extreme importance for the accomplishment of the present research, because a similar method was employed, making it possible to compare the size of the malignant lesions before and after treatment. In order to use this methodology, some parameters were established, such as: the use of the same protocol to acquire images from all patients, intravenous contrast infusion, all examiners were submitted to previous training, measurements were checked at three different times and were also taken by two different examiners.

Other methods of measuring volume of pathological processes have been suggested. In most studies, the calculation has been done by adding the areas obtained in each tomographic slice and then multiplying them by the thickness of the cut ${ }^{4,5,12,16,19,20,22,23}$. In spite of the high correlation level between the size of the tumor obtained through the use of this methodology and the histopathologic examination, this technique has some drawbacks, especially in invasive lesions (and in small ones), situations in which it is extremely difficult to delineate the lesion ${ }^{4}$.

$\mathrm{CT}$ is considered to be a sensitive method for assessing primary malignant tumors (size, location, spread to soft tissues and regional lymph node metastasis) ${ }^{17}$. However, its ultimate usefulness in the delineation of invasion of these tumors in the mandible remains questionable for many authors $^{2,5,10,17}$. The related literature shows high

\section{REFERENCES}

1. Alder ME, Deahl ST, Matteson SR. Clinical usefulness of two-dimensional reformatted and three-dimensional rendered computerized tomographic images: literature review and a survey of surgeons' opinions. J Oral Maxillofac Surg 1995;53:375-86.

2. Bahadur S. Mandibular involvement in oral cancer. J Laryngol Otol 1990;104:968-71.

3. Baum U, Greess H, Lell M, Nomayr A, Lenz M. Imaging of head and neck tumors - methods: CT, spiral-CT, multislice-spiral-CT. Eur J Radiol 2000;33:153-60. false positive and false negative rates when determining bone invasion ${ }^{2,5,17}$, because $4 \mathrm{~mm}$ and $5 \mathrm{~mm}$ thick axial slices are used. Most authors suggest that thin slices are needed to detect more bone details ${ }^{5,10,17}$. In our experiment, we observed better results since we used $3 \mathrm{~mm}$ thick slices with a $1.5 \mathrm{~mm}$ interval of reconstruction. The 3D segmentation protocol demonstrated high imaging resolution, with high specificity and sensitivity to determine the lesion components. Also, the artifacts in CT scan can limit the observation of local invasion of malignant tumors, due to dental fillings (basically amalgam) and bone shape ${ }^{2,7,10,17}$. For that reason, we believe that using $3 \mathrm{D}-\mathrm{CT}$ images by volume rendering technique can improve the visualization and thus clarify the anatomical patterns of tumors. Therefore, we obtained satisfactory results since only 3 false negatives resulted with the employment of axial and MPR-CT images. It was not possible to identify bone damage in 3 of the 17 analyzed cases (confirmed by the histopathologic studies), whereas with 3D-CT no false negative was found. Furthermore, employing MPR-CT and 3D-CT reconstructed images with the specific protocol (segmentation), we demonstrated that the use of this methodology can be an important aid to minimize errors ${ }^{6}$.

\section{CONCLUSION}

In conclusion, this study can be used as a parameter for future studies, based on established protocols for the treatment planning and follow-up of patients with maxillofacial malignant lesions.

\section{ACKNOWLEDGMENTS}

CNPq, Brasília, Brazil (Dr. Marcelo Cavalcanti, Grant \# 309331/2003-0). We thank the Vice-Rectorate for Research, University of São Paulo, for the financial aid to publish colored figures.

4. Bilimoria MM, Holtz DJ, Mirza NQ, Feig BW, Pisters PWT, Patel S, et al. Tumor volume as a prognostic factor for sarcomatosis. Cancer 2002;94:2441-6.

5. Brown JS, Griffith JF, Phelps PD, Browne RM. A comparison of different imaging modalities and direct inspection after periosteal stripping in predicting the invasion of the mandible by oral squamous cell carcinoma. Br J Oral Maxillofac Surg 1994;32:347-59.

6. Cavalcanti MGP, Ruprecht A, Bonomie JM, Vannier MW. The validation of 3D spiral CT-based measurements of 
Cavalcanti MGP, Santos DT, Perrella A, Vannier MW. CT-based analysis of malignant tumor volume and localization. A preliminary study. Braz Oral Res 2004;18(4):338-44.

simulated maxillofacial neoplasms. Oral Surg Oral Med Oral Pathol Oral Radiol Endod 2000;89:753-8.

7. Cavalcanti MGP, Ruprecht A, Quets J. Progression of maxillofacial squamous cell carcinoma evaluated using computer graphics with spiral computed tomography. Dentomaxillofac Radiol 1999;28:238-44.

8. Cavalcanti MGP, Ruprecht A, Vannier MW. 3D-CT vascular setting protocol using computer graphics for the evaluation of maxillofacial lesions. Pesqui Odontol Bras 2001;15:22936.

9. Cavalcanti MGP, Vannier MW. Measurement of the volume of oral tumors by three-dimensional spiral computed tomography. Dentomaxillofac Radiol 2000;29:35-40.

10. Close LG, Burns DK, Merkel M, Schaefer SD. Computed tomography in the assessment of mandibular invasion by intraoral carcinoma. Ann Otol Rhinol Laryngol 1986;95:383-8.

11. Covino SW, Robin JM, Shprintzen RJ, Cisneros GJ. The accuracy of measurements of three-dimensional computed tomography reconstructions. J Oral Maxillofac Surg 1996;54:982-90.

12. Doweck I, Denys D, Robbins KT. Tumor volume predicts outcome for advanced head and neck cancer treated with targeted chemoradiotherapy. Laryngoscope 2002;112:1742-9.

13. Fagelman D, Huang A. Prospective evaluation of lesions of the mandible and maxilla: findings on multiplanar and three-dimensional CT. Am J Roentgenol 1994;163:693-8.

14. Franca C, Levin-Plotnik D, Sehgal V, Chen GTY, Ramsey RG. Use of three-dimensional spiral computed tomography imaging for staging and surgical planning of head and neck cancer. J Dig Imag 2000;13:24-32.

15. Greess H, Nomayr A, Tomandl B, Blank M, Lell M, Lenz $\mathrm{M}$, et al. 2D and 3D visualisation of head and neck tumours from spiral-CT data. Eur J Radiol 2000;33:170-7.
16. Hermans R, Feron M, Bellon E, Dupont P, Bogart WV, Baert AL. Laryngeal tumor volume measurements determined with CT: a study on intra- and interobserver variability. Int J Radiat Oncol Biol Phys 1998;40:553-7.

17. Kalavrezos ND, Gratz KW, Sailer HF, Stahel WA. Correlation of imaging and clinical features in the assessment of mandibular invasion of oral carcinomas. Int J Oral Maxillofac Surg 1996;25:439-45.

18. Kuriakose MA, Loree TR, Hicks WL, Welch JJ, Wang $\mathrm{H}$, DeLacure MD. Tumour volume estimated by computed tomography as a predictive factor in carcinoma of the tongue. Br J Oral Maxillofac Surg 2000;38:460-5.

19. Nathu RM, Mancuso AA, Zhu TC, Mendenhall WM. The impact of primary tumor volume on local control for oropharyngeal squamous cell carcinoma treated with radiotherapy. Head Neck 2000;22:1-5.

20. Pameijer FA, Balm AJM, Hilgers FJM, Muller SH. Variability of tumor volumes in T3-staged head and neck tumors. Head Neck 1997;19:6-13.

21. Ray CE, Mafee MF, Friedman M, Tahmoressi CN. Applications of three-dimensional $\mathrm{CT}$ imaging in head and neck pathology. Radiol Clin North Am 1993;31:181-94.

22. Shin K, Moon S, Suh J, Yang W. Tumor volume change as a predictor of chemotherapeutic response in osteosarcoma. Clin Orthop Res 2000;376:200-8.

23. Sohaib SA, Turner B, Hanson JA, Farquharson M, Oliver RT, Reznek RH. CT assessment of tumor response to treatment: comparison of linear, cross-sectional and volumetric measures of tumor size. Br J Radiol 2000;73:117884.

24. Szklo M, Javier-Nieto F. Epidemiology: beyond the basics. Gaithersburg: Aspen; 2000.

25. Xia J, Samman N, Yeung RWK, Wang D, Shen SGF. Computer-assisted three-dimensional surgical planning and simulation. Int J Oral Maxillofac Surg 2000;29:250-8.

Received for publication on Jun 17, 2004

Sent for alterations on Aug 18, 2004 Accepted for publication on Oct 06, 2004 